\title{
МЕТОДИЧНІ АСПЕКТИ ВИКЛАДАННЯ ТОКСИКОЛОГІЧНОЇ ТА СУДОВОЇ ХІМІЇ ВІТЧИЗНЯНИМ СТУДЕНТАМ
}

\author{
N. V. Horlachuk, N. O. Zarivna, L. M. Mosula \\ I. Horbachevsky Ternopil National Medical University

\section{METHODOLOGICAL ASPECTS OF TEACHING TOXICOLOGICAL AND FORENSIC CHEMISTRY FOR DOMESTIC STUDENTS}

\begin{abstract}
Анотація. Викладено основні методичні підходи до викладання дисципліни «Судова та токсикологічна хімія» вітчизняним студентам фармацевтичного факультету, спеціальності «Фармація». Базовими завданнями вищої школи є підготовка фахівців, що володіють глибокими знаннями фундаментальних та прикладних дисциплін і вміють творчо застосовувати ці знання для вирішення різноманітних завдань. Розроблена дисципліна включає курс лекцій, методичні вказівки до практичних робіт і підготовки до лекцій та занять, які доступні в системі Moodle. Лекційний курс представлений у вигляді мультимедійних презентацій з десяти тем та охоплює класифікацію токсичних речовин, методи ізолювання отрут із біологічного матеріалу, їх ідентифікацію та кількісне визначення. Дисципліна включає дванадцять практичних робіт, на яких проводять хімікотоксикологічний аналіз та судово-токсикологічне дослідження об'єктів біологічного походження на наявність і вміст отруйних речовин різної природи і характеру.
\end{abstract}

Ключові слова: отруйні речовини; судова та токсикологічна хімія; хіміко-токсикологічний аналіз.

Abstract. The main methodological approaches to teaching the discipline of Toxicological and Forensic Chemistry for the domestic students of the pharmaceutical faculty, specialty "Pharmacy, Industrial Pharmacy" are set forth. The basic tasks of the higher school are the training of specialists with deep knowledge of fundamental and applied disciplines and are able to apply this knowledge creatively to solve various tasks. The developed discipline includes course of lectures, methodical instructions for practical works and preparation for lectures and classes, which are available in the Moodle system. The lecture course is presented in the form of multimedia presentations of ten topics and covers the classification of toxic substances, methods of isolation of poisons from biological material, their identification and quantification. The discipline includes twelve practical works, on which the chemical-toxicological analysis and forensic toxicological research of biological origin objects for the presence and content of poisonous substances of different nature and character.

Key words: toxic substances; forensic and toxicological chemistry; chemical and toxicological analysis.

Вступ. Стратегічні напрями реорганізації вітчизняної системи вищої медичної та фармацевтичної освіти визначаються як внутрішньодержавними процесами, так і тенденціями загальносвітового розвитку, а відтак передбачають приведення іiї структури, змісту та якості у відповідність і до державних потреб та вимог системи охорони здоров’я,

(с) Н. В. Горлачук, Н. О. Зарівна, Л. М. Мосула і до міжнародних стандартів. Вища медична освіта повинна забезпечити високоякісну підготовку студентів і $є$ важливою складовою реформування галузі охорони здоров'я та реалізації соціальних пріоритетів держави, оскільки від рівня підготовки майбутніх лікарів залежить якість надання медичної допомоги населенню країни. Сучасний розвиток медичної науки і практики зумовлює 
необхідність вносити корективи в підготовку та підвищення кваліфікації медичних працівників із наближенням їх освіти до міжнародних стандартів. Саме тому якість освіти у вищих навчальних закладах необхідно покращити шляхом ефективної організації та інформатизації навчального процесу, впровадженням передових наукових розробок у практику викладання, забезпеченням високого професіоналізму викладачів, створенням сучасної навчально-методичної бази в усіх освітніх галузях, зокрема і медичній $[1,6,8]$.

Мета статті - вивчення методичних аспектів викладання дисципліни «Токсикологічна та судова хімія» для студентів 4 курсу фармацевтичного факультету Тернопільського національного медичного університету імені І. Я. Горбачевського (спеціальність 226 «Фармація, промислова фармація», денної форми навчання).

Теоретична частина. Навчальна дисципліна «Токсикологічна та судова хімія» належить до циклу дисциплін професійно-орієнтованої підготовки фахівців за напрямком «Фармація».

Знайомство людини з отрутою відбулося в ті далекі часи, коли наші предки вперше зіткнулися з отруйними тваринами та рослинами. Основними джерелами отруєння були високотоксичні речовини рослинного походження - алкалоїди та глікозиди (стрихнін, аконіти, дурман, цикута). У період середньовіччя випадки отруєння траплялися часто, а найчастіше як отруту використовували миш'як [4].

Наука, яка виникла декілька століть тому і вивчає методи дослідження отрут у внутрішніх органах, у біологічних рідинах й інших об’єктах, одержала назву судової хімії. Із розвитком хімії, хімічної промисловості та фармації збільшилася кількість фармацевтичних препаратів і речовин, які використовувались у різних сферах діяльності. Велика кількість цих речовин була отруйною. Більше 6 млн найменувань хімічних сполук, які містяться в навколишньому середовищі, становлять потенційну небезпеку для здоров’я населення. В останні роки спостерігається зростання смертельних отруєнь алкоголем і його сурогатами, а також лікарськими засобами психотропної та наркотичної дії. Раніше використання наркотиків було проблемою окремих груп населення. У даний час сучасна людина проживає в умовах токсикологічної напруженості, яка обумовлена технологічними та екологічними катастрофами, професійними вадами, нещасними випадками у побуті, а також різними захворюван- нями хімічної етіології, які виникають 3 кримінальних чи суїцидних причин [7].

У зв'язку з цим виникає необхідність своєчасного виявлення і попередження даного виду патології. Важливою особливістю токсикологічної хімії $€$ зростання номенклатури токсичних речовин внаслідок впровадження у всі сфери життєдіяльності людини нових хімічних сполук і речовин [3, 5]. Токсикологічна хімія є однією з профільних дисциплін у системі вищої фармацевтичної освіти. Курс токсикологічної та судової хімії грунтується на знаннях, одержаних при вивченні інших фундаментальних дисциплін, зокрема аналітичної та фармацевтичної хімії, тому інтегрується $з$ ними. Метою викладання вищевказаної дисципліни є забезпечення майбутнього фахівця фармацевтичної галузі такими спеціальними знаннями, уміннями та практичними навичками, які дадуть йому можливість повноцінно і якісно виконувати свої професійні обов’язки.

Під час викладання токсикологічної та судової хімії студенти вивчають властивості отруйних та сильнодіючих речовин, їх поведінку в організмі живої людини або у трупному матеріалі, методи ізолювання отрут, якісного й кількісного визначення та їх метаболітів [2]. Велике значення має токсикологічна хімія в діагностиці отруєнь, у боротьбі зі злочинами. Висновки хіміків-токсикологів про наявність або відсутність і кількість отрути в досліджуваних об’єктах надають величезну допомогу судово-медичним експертам для встановлення причин отруєнь, слідчим органам у розкритті злочинів. Висновки хіміків-токсикологів, гігієністів, фармакологів про високу токсичність окремих фармацевтичних препаратів і речовин, які використовуються в народному господарстві, є підставою для припинення використання цих препаратів або їх заміни, зберігання і порядку реалізації населенню. Результати хіміко-токсикологічних та санітарногігієнічних досліджень повітря і стічних вод промислових підприємств, які містять токсичні речовини, використовуються органами санітарної охорони для початку процедури вимоги будівництва або реконструкції очисних споруд [9].

Основними розділами токсикологічної та судової хімії $є$ біохімічна та аналітична токсикологія. При розгляді основ біохімічної токсикології в курсі токсикологічної хімії особливу увагу слід приділяти вивченню фізико-хімічних властивостей токсичних речовин, питанням токсикокінетики, біотранформації отруйних речовин в організмі людини. При 
цьому необхідно виділити основні загальнотеоретичні положення і закономірності.

Важливим моментом в аналітичній токсикології залишається розгляд положень, які зв'язані з підготовкою проб, включаючи ізолювання, очистку і концентрування токсичних речовин у різноманітних об’єктах. Для кожного біооб’єкта необхідно передбачити коректний відбір і зберігання проби, схему та метод екстракції, наявність екзогенних та ендогенних сполук. Задачею хіміко-токсикологічного аналізу є визначення нанограмових кількостей речовин на фоні ряду ендогенних речовин біоматриці, при цьому висуваються чіткі вимоги до проведення стадій проб підготовок [12].

Майбутньому фахівцю у фармацевтичній галузі необхідно навчитися правильно вибирати методи ізолювання отруйних речовин із біологічного матеріалу трупа та проводити відповідні методи ідентифікації цих отрут. Велику увагу у викладанні токсикологічної та судової хімії необхідно приділити кількісним методам аналізу. При цьому має розглядатися не тільки сутність методу визначення, але й спосіб визначення.

В останні десятиліття поряд із традиційними методами хіміко-токсикологічного аналізу (мікрокристалоскопічні та кольорові реакції, ТШХ, ГХ, BEPX, спектральні методи) пріоритетного значення набувають імунохімічні методи. Ці сучасні методи аналізу (радіоімунний, імуноферментний, люмінесцентний) відрізняються високою чутливістю, специфічністю, простотою виконання [10]. Тепер широко використовують комп'ютеризований метод газової хроматографії з мас-спектральним детектуванням (ГХ/MC), перевагами якого є висока точність і чутливість. Ідентифікація речовин значно полегшується завдяки комп’ютерному пошуку програмного забезпечення. База даних, яка використовується в ГХ/МС системі, включає 50000 лікарських і токсичних речовин та їх метаболітів [11].

Детальне і грунтовне ознайомлення з основами дисципліни «Токсикологічна та судова хімія» дає можливість більш повно засвоїти матеріал, що вивчається, реалізувати науково-творчий потенціал студентів, збагачує їх знаннями, які безпосередньо будуть використані в майбутній практичній діяльності.

Для освоєння матеріалу згідно з кредитно-модульною системою виділено 20 год лекцій, 72 год практичних занять, 28 год самостійної роботи студентів (СПРС) та 6 практичних навичок. Така невелика кількість аудиторних годин вимагає від викладача дуже ретельного підходу до відбору навчального матеріалу та методики його представлення. Лекційний курс має спонукати студента переходити від пасивного запам’ятовування до практичного використання одержаних знань. На практичних заняттях студенти повинні навчитися складати план проведення хіміко-токсикологічного аналізу із використанням комплексу хімічних та фізико-хімічних методів дослідження, проводити ізолювання токсичних речовин із біологічних об’єктів. Ці знання необхідні для судової експертизи при направленому і ненаправленому аналізі на токсикологічні речовини, із ціллю діагностики гострих отруєнь у судово-токсикологічних лабораторіях бюро судово-медичної експертизи [12].

У кінці семестру передбачено семестровий тестовий іспит. При вивченні даної дисципліни студентам читаються лекції з мультимедійним супроводом, які сприяють всебічному сприйняттю викладеного матеріалу та повнішому його засвоєнню. На лекцію студенти приходять підготовленими, оскільки матеріали підготовки до лекцій розміщені на Web-порталі університету.

Практичні заняття з даної дисципліни проводяться згідно з методикою «єдиного дня», відповідно до якої навчання студентів становить 5 робочих днів, 3 яких 1 день призначений для лекцій та 4 дні - для практичних занять. Кожне практичне заняття забезпечене методичними рекомендаціями, матеріалами підготовки до практичного заняття, тестовими завданнями для контролю знань, ситуаційними задачами та методичними вказівками для самостійної роботи студентів.

На практичних заняттях 3 токсикологічної та судової хімії велика увага приділяється питанням токсикодинаміки, токсикокінетики, біотрансформації та класифікації ксенобіотиків. Особлива увага надається методам проб підготовки, зокрема, відпрацьовуються методи рідинної та твердофазної екстракції, мінералізації, перегонки із водяною парою та діалізу. Сучасні методи аналізу знаходять широке застосування у токсикологічній хімії. На заняттях студенти набувають практичних навичок із застосуванням мікрокристалоскопічного, спектрального і хроматографічного аналізу. В практику включені методи ізолювання «лікарських отрут» загальними та спеціальними методами. Як підсумок вивченого для кожного студента пропонується написати «Акт судово-хімічного дослідження».

Викладачі постійно працюють над вдосконаленням необхідного навчально-методичного забезпе- 
чення дисципліни, прагнуть домогтися засвоєння знань, практичних навичок, сприяють формуванню наукового світогляду, моральних, естетичних та інших якостей особистості, вихованню колективу. Також орієнтуються на потреби студента у певних знаннях, уміннях і навичках з опорою на подальшу самоосвіту, оскільки в навчальному закладі не закінчується формування особистості спеціаліста, воно продовжується все життя впродовж практичної діяльності і безперервного підвищення кваліфікації.

Висновки та перспективи подальших досліджень. Для підготовки студентів фармацевтич-

\section{Список літератури}

1. Бойчук І. Д. Передумови виникнення та становлення системи підготовки фармацевтів в Україні / І. Д. Бойчук // Педагогіка і психологія професійної освіти: наук.-метод. журнал. - Львів, 2007. - № 4. - С. 186-196.

2. Вергун О. М. Особенности профессиональной направленности преподавания токсикологической химии студентам фармацевтического факультета / О. М. Вергун, Н. Д. Яранцева // Вестник фармации. 2017. - № 30. - С. 62-65.

3. Евстигнеева В. П. Актуальность преподавания предмета токсикологическая химия в курсе подготовки провизоров / В. П. Евстигнеева, И. В. Шкутина, Т. А. Брежнева // Вестник ВГУ. - 2016. - № 1. - С. 46-49.

4. Калетина Н. И. Токсикологическая химия: метаболизм и анализ токсикантов : учебное пособие / Н. И. Калетина. - М., 2018. - 697 с.

5. Кузнецова Н. И. История и современность токсикологической химии. Совершенствование преподавания дисциплины / Н. И. Кузнецова, Г. В. Раменская // Сеченовский вестник. - 2014. - № 3. - С. 36-40.

6. Підаєв А. В. Болонський процес в Європі / А. В. Підаєв. - К., 2004. - 191 с.

\section{References}

1. Boichuk, I.D. (2007). Peredumovy vynyknennia ta stanovlennia systemy pidhotovky farmatsevtiv v Ukraini [Prerequisites for the emergence and development of a pharmacists training system in Ukraine]. Pedahohika $i$ psykholohiia profesiinoi osvity - Pedagogy and Psychology of Professional Education, 4, 186-196 [in Ukrainian].

2. Verhun, O.M., \& Yarantseva, N.D. (2017). Osobennosti professyonalnoy napravlennosti prepodavaniya toksikologicheskoy khimii studentam farmatsevtycheskogo fakulteta [Features of the professional orientation of teaching toxicological chemistry to students of Pharmacy Faculty]. Vestnyk farmatsii - Bulletin of Pharmacy, 30,62-65 [in Russian]. ного факультету важливе місце займає вивчення дисципліни «Токсикологічна та судова хімія». Дуже важливо формувати в студентів фармацевтичного факультету в процесі вивчення даної дисципліни системний підхід до вивченого, розвивати в них логічне мислення, уміння аналізувати, порівнювати, прогнозувати та використовувати отримані знання і вміння у майбутній професійній фармацевтичній діяльності. Перспективи подальших досліджень вбачаємо у вивченні та аналізі особливостей викладання даної дисципліни у провідних вітчизняних та закордонних вищих навчальних закладах освіти фармацевтичного профілю.

7. Токсикологическая химия : учебник / под ред. Т. В. Плетеневой. - 4-е изд. - М., 2016. - 512 с.

8. Черних В. Фармацевтична галузь за роки незалежності України / В. Черних // Вісник фармації. 2002. - № 3. - C. 3-12.

9.. Falcone J. S. Toxicology in the undergraduate forensic chemistry curriculum / J. S. Falcone, J. J. Fenton // 228th ACS National Meeting: Abstractsof Papers (Philadelphia, PA, United States, August 22-26, 2004). - Philadelphia, 2004. - P. 66-68.

10. Liquid chromatography / S. Fanali, P. R. Haddad, C. Poole, M.-L. Riekkola. - Saint Louis : Elsevier Science, 2017. - 838 p.

11. Vandergrift G. W. Paper spray mass spectrometry: A new drug checking tool for harm reduction in the opioid over dose crisis / G. W. Vandergrift, C. G. Gill // Journal of Mass Spectrometry. - 2019. - Vol. 54, No. 9. - P. 729-737.

12. Welchinska E. The use of forensic chemistry methods in the determination of counterfeit drugs / E. Welchinska, V. Velchynskyi // International Conference on Innovations in Science and Education: CBU International Conference Proceedings (Prague, Czech Republic, March 20-22, 2019) / ISE Research Institute. - Prague, 2019. - P. 858-863.

3. Evstyhneeva, V.P., Shkutyna Y.V., \& Brezhneva, T.A. (2016). Aktualnost prepodavaniya predmeta toksykologicheskaya khimiya v kurse podgotovki provizorov [The relevance of teaching the subject of toxicological chemistry in the course of pharmacist training]. Vestnyk VHU - Bulletin of VSU, 1, 46-49 [in Russian].

4. Kaletina, N.Y. (2018). Toksykologicheskaya khimiya: metabolizm i analiz toksykantov [Toxicological chemistry: metabolism and analysis of toxicants]. Moscow [in Russian].

5. Kuznetsova, N.Y., \& Ramenskaya, H.V. (2014). Istoriya i sovremennost toksikologicheskoy khimii. Sovershenstvovanye prepodavaniya dystsypliny [History 
and modernity of toxicological chemistry. Improving teaching discipline]. Sechenovskiy vestnyk - Sechenov Bulletin, 3,36-40 [in Russian].

6. Pidaiev, A.V. (2004). Bolonskyi protses v Yevropi [The Bologna Process in Europe]. Kyiv [in Ukrainian].

7. Pleteneva, T.V. (2016). Toksikologicheskaya khimiya [Toxicological chemistry]. Moscow [in Russian].

8. Chernykh, V. (2002). Farmatsevtychna haluz za roky nezalezhnosti Ukrainy [The pharmaceutica lindustry during the years of independence of Ukraine]. Visnyk farmatsii Bulletin of Pharmacy, 3, 3-12 [in Ukrainian].

9. Falcone, J.S., \& Fenton, J.J. (2004). Toxicology in the undergraduate forensic chemistry curriculum. 228th ACS NationalMeeting: AbstractsofPapers.UnitedStates, Philadelphia, PA, August 22-26 (pp. 66-68).
10. Fanali, S., Haddad, P.R., Poole, C., \& Riekkola, M.-L. (2017). Liquid chromatography. SaintLouis: ElsevierScience. DOI: 10.1016/B978-0-12-805392-8.00011-6.

11. Vandergrift, G.W., \& Gill, C.G. (2019). Paper spray mass spectrometry: A new drug checking tool for harm reduction in the opioid overdose crisis. Journal of Mass Spectrometry, 9 (54), 729-737. DOI: 10.1002/jms.4431.

12. Welchinska, E., \& Velchynskyi, V. (2019). The use of forensic chemistry methods in the determination of counterfeit drugs. International Conference on Innovations in Science and Education: CBU International Conference Proceedings. Czech Republic, Prague, March 20-22. ISE Research Institute. DOI: 10.12955/cbup.v7.1467. 